\title{
Allium sativum
}

National Cancer Institute

\section{Source}

National Cancer Institute. Allium sativum. NCI Thesaurus. Code C54084.

Garlic plants are closely related to and similar to onions and they have a similar, but stronger odor. The leaves of garlic plants are neither inflated like onion leaves nor tubular like those of bunching onions. Instead, they are flat, with a crease down the middle and are held erect in two opposite ranks. Most varieties stand about 1-2 ft (0.3-0.6 m) tall at maturity. Garlic plants produce an underground bulb that usually is divisible into 6-20 segments, called cloves. Garlic contains compounds that are antibacterial, antifung al and reduce blood clotting. 